\title{
PEDRO PAULO ABREU FUNARI: UM ARQUEÓLOGO DO MUNDO
}

Carlos Fabião ${ }^{1}$

Pedro Paulo Abreu Funari é um importante cientista social, principalmente nos campos da Arqueologia e da História Antiga, mas também possui contribuições bastante relevantes em diversas outras áreas, dentro de um campo que pode ser definido como o das questões teóricas de História e Arqueologia. O reconhecimento do seu trabalho científico e acadêmico pelos seus colegas está claramente expresso nas mais de cinco mil menções registradas na base de dados Google Scholar (https://scholar.google.com.br/citations? user=gQgnsTgAAAAJ\&hl=pt-BR). Esta útil ferramenta de avaliação acadêmica também registra 20 coautores para os seus artigos e livros, provenientes de diferentes ambientes acadêmicos geográficos, da Europa aos Estados Unidos da América, na América do Sul e - como se pode prever - com um destaque maior no Brasil.

A lista de artigos e livros do Prof. Funari revela o quanto ele é um autor multilíngue: o português, o espanhol, o inglês e o francês são alguns dos idiomas utilizados em suas obras. Tais habilidades multilíngues podem também ser vistas como uma declaração cultural contra tendências predominantes e modismos de pesquisa: o mundo é diversificado, e sua diversidade deve se refletir na produção dos cientistas.

Essa visão geral a partir da base Google Scholar apresenta-nos um autor com uma perspectiva ampla, sem apegos a uma afiliação acadêmica específica, e voltado à diversidade. Por meio dela, encontramos alguém consciente da grande transformação vivenciada pela ciência arqueológica no seu tempo, e com um forte compromisso com o que foi denominado de 'Arqueologia do Futuro' na seminal declaração do Congresso Arqueológico Mundial (WAC, na sigla em inglês): "Isto, na verdade, é a arqueologia do futuro. A disciplina da arqueologia já não é mais uma província exclusiva de homens brancos, europeus e de alta classe. E já não é mais possível voltarmos a uma era pré-WAC de conhecimento excludente, hierárquico e cientificizado, que marginalize a arqueologia

\footnotetext{
1 Professor Associado. Universidade de Lisboa, Lisboa, Portugal. E-mail: cfabaiao@campus.ul.pt
} 
multivocal das periferias. A pergunta 'quem controla o passado?' já não é mais um enigma, pois se deve, em geral, consentir que haja muitos passados, e que eles serão conhecidos de diferentes maneiras a partir de diversas visões" (http://worldarch.org/history-wac/).

De acordo com sua própria experiência e com o seu compromisso ético pessoal, Funari se tornou não apenas um parceiro nesta grande mudança geracional, mas também um atuante promotor do seu processo, contribuindo regularmente às Conferências e aos periódicos do WAC. Funari foi também responsável pela ampla difusão dessas perspectivas na comunidade lusófona, e por este motivo escolhi para ele o epíteto de um "Arqueólogo do Mundo".

Lancemos agora nosso olhar ao início das atividades científicas do Prof. Funari, valendo-nos para isto do seu texto autobiográfico contido na publicação de 2013 que traça um panorama da Arqueologia Clássica no Brasil (Grillo; Funari; Carvalho, 2013).

Em seu testemunho, Funari descreve sua inclinação inicial pelas questões filosóficas e teóricas, e também o objetivo específico de estudar regimes ditatoriais - uma tarefa de difícil realização no contexto de um regime totalitário. Porém, ao final, estudou História Antiga, em particular, História Econômica Romana. Pode-se dizer, nesse sentido, que "não há amor como o primeiro amor", e que isso é capaz de explicar a maneira como Funari, mais adiante, abordou suas questões teóricas e também a arqueologia da repressão, com sua expressão ibero-americana.

No campo da História Econômica Romana, Funari escolheu trabalhar com algumas fontes peculiares: por um lado, as ânforas - os recipientes romanos típicos que transportavam alimentos de uma região para outras. Utilizou, assim, artefatos arqueológicos para investigar a conectividade interprovincial dentro do Império Romano. Mas também tratou de questões epigráficas ligadas às ânforas, aos selos, aos elementos mais relevantes da vida dos centros fabris, e às dipinti, isto é, as inscrições cursivas pintadas à mão, relacionadas a questões comerciais. É importante salientar que essas áreas de pesquisa são bastante complexas e específicas, e por isso Funari precisou ir à Europa para obter a formação adequada junto aos especialistas sêniores do campo, a fim de lidar com essas fontes históricas tão diferentes.

Em um dos seus primeiros artigos científicos publicados a respeito dos estudos sobre ânforas, Funari nos apresenta as diretrizes de sua pesquisa, combinando literatura clássica, a leitura e interpretação das dipinti, e estudos sobre cerâmicas em uma abordagem a um só tempo eclética e 
coerente (Funari, 1986). Externa também sua gratidão a alguns pesquisadores europeus de destaque nessa matéria, provenientes da Itália, da Espanha e da França, em uma expressiva demonstração de sua abertura a diferentes escolas de pesquisas. É importante apontar que esse paper ainda não faz qualquer referência a estudiosos britânicos.

Mais adiante, Funari se muda para a Grã-Bretanha para estudar evidências das exportações de azeite de oliva bético àquela província romana ao norte, em uma linha de pesquisa que se converteu em uma das suas principais contribuições aos estudos econômicos romanos e foi publicada em um livro com Cesar Carreras Monfort neste tema (Carreras Monfort; Funari, 1998).

Funari chega à Grã-Bretanha e trabalha no ambiente acadêmico local, valendo-se de sua formação não britânica anterior - o que explica sua abordagem singular e independente. Escolhe os mais relevantes centros científicos para ampliar suas já bem desenvolvidas habilidades: a Universidade de Southampton para estudos de ceramologia e anforologia (http://archaeologydataservice.ac.uk/archives/view/amphora_ahrb_2005/), e o grupo CEIPAC em Barcelona para o campo da epigrafia de ânforas (http://ceipac.ub.edu/).

Retorna diversas vezes ao tema da distribuição e do consumo de azeite de oliva, realizando novas e importantes contribuições - como Funari, 2008, para citar apenas uma delas -, e expressando suas considerações quanto ao uso de uma abordagem teórica consistente no estudo dos padrões militares e não militares de consumo de azeite de oliva na província romana da Bretanha.

Mais recentemente, Funari ingressa na linha de pesquisas relativas à arqueologia da violência e da repressão na América ibérica, realizando assim o seu objetivo primordial de estudar as ditaduras. Atua, desta vez, em um contexto livre e democrático, que não era possível nos anos iniciais de sua juventude. Uma vez mais, demonstra seu compromisso com o espírito do WAC, calcado em uma arqueologia ética e politicamente engajada, e não na atitude supostamente asséptica dos anos pré-WAC. Em outras palavras, empenha-se em ser um agente da grande mudança científica na arqueologia, citada mais ao início deste texto.

Outros trabalhos recentes escritos por Funari abordam a disciplina da Arqueologia Pública, que, na atualidade, tornou-se bastante popular. Esta, na verdade, era uma antiga preocupação sua, que remonta à Quinta Conferência do WAC em Washington e, desde então, tornou-se uma questão regularmente tratada nos seus artigos. Outra linha de pesquisa 
por ele abordada é a linha conhecida como arqueologia histórica - uma disciplina também recorrente no seu trabalho científico e um dos grandes campos de pesquisa no âmbito do Congresso Arqueológico Mundial, que reflete a abertura da Arqueologia a outras geografias de pesquisa diferenciadas e não europeias.

Este brevíssimo relato a respeito da trajetória de Pedro Paulo Abreu Funari deve também enfatizar sua grande contribuição ao ensino e à formação de estudantes de diferentes níveis acadêmicos, da graduação ao doutoramento. Nesses campos fundamentais, Funari aportou com uma sólida contribuição ao desenvolvimento da arqueologia brasileira, como podemos observar nas frequentes menções feitas em diversas contribuições na obra a respeito do desenvolvimento da Arqueologia Clássica no Brasil (Grillo; Funari; Carvalho, 2013). A meu ver, essa grande influência está igualmente presente em algumas de suas compilações de textos clássicos, reunidas com objetivos pedagógicos e utilizadas pelos estudantes, e em diversos artigos curtos publicados em jornais ou resenhas de livros, onde Funari é sempre citado como uma importante referência para qualquer estudante de Arqueologia e do Mundo Antigo.

Definitivamente, Pedro Paulo Abreu Funari é um Arqueólogo do Mundo com um trabalho acadêmico vasto e bem consolidado, sempre realizado com um rigoroso enquadramento teórico e com uma firme postura ética, que é e deve ser um modelo para os estudantes e colegas acadêmicos.

\section{Referências}

Carreras Monfort, C.; Funari, P. P. A. (1998): Britannia y el Mediterráneo: Estudios sobre el abastecimiento de aceite bético y africano en Britannia. Barcelona: Publicaciones de la Universitat de Barcelona (Collecció Instrumenta, 5).

Funari, P. P. A. (1986) Em torno da ânfora. A terminologia latina dos vasos recipientes. Revista de Guimarães, 96, p. 219-227.

Funari, P. P. A. (2008) La contribution d'une approche postprocessual pour la comprehension de la consommation d'huile d'olive en Bretagne romaine. Stodia Historica / Historia Antigua, 26, p. 271-302.

Grillo, José Geraldo Costa; Funari, Pedro Paulo A.; Carvalho, Aline Vieira de (Eds.) (2013) Os caminhos da arqueologia clássica no Brasil: depoimentos. São Paulo: Annablume (Coleção História e Arqueologia em Movimento). 